\title{
Human resource management in the construction of a sustainable development project: towards successful completion
}

\author{
I. Othman, A. Idrus \& M. Napiah \\ Department of Civil Engineering, Universiti Teknologi Petronas, \\ Perak, Malaysia
}

\begin{abstract}
Construction projects are facing many problems from day to day in their business. One of the problems that has been taken into consideration in this study is human resource management in the construction of a sustainable development project. Even though construction uses more manpower in its business activities compared to other fields, its human resource management is still inadequate and insufficient. The problem concerning human resource management in the construction of a sustainable development project needs to be identified and methods for improvement need to be formulated for the success of the project. A combination of questionnaire survey and case study were used as methodologies for this study. 150 questionnaires were distributed to contractors all over Malaysia and we received 25 feedbacks. A case study was undertaken at a construction site in Kuala Lumpur. The results of the study show that there was awareness among the contractors in Malaysia about the importance of human resource management on the success of construction of a sustainable development project. The main problems of human resource management in the construction of a sustainable project have been identified. There were project managers' roles, communication between team members and insufficient teamwork. The main methods for improvement have also been discovered; namely, more communication among team members, the appointment of a more experienced project manager and the assignment of more skilled workers.

Keywords: sustainable development, construction, human resource management, improvement, successful completion.
\end{abstract}




\section{Introduction}

Construction is a process that consists of the building or assembling of an infrastructure. Large scale construction is a feat of multi-tasking. Normally the job is managed by the project manager and supervised by the construction manager, design engineer, construction engineer or project architect [1]. For the success of construction of any sustainable development project, many aspects must be taken into consideration, inclusive of planning and management, such as human resource, safety and health, construction delays, the designs of architecture and engineering, material availability and quality; the clients need, and financial or economic limitations. One of the aspects which is crucial in this study is human resource management. The term 'human resource management' (HRM) and 'human resources' (HR) have largely replaced the term 'personnel management' as a description of the processes involved in managing people in organizations. In simple words, HRM means employing people, developing their capacities, utilizing, maintaining and compensating their services in tune with the job and organizational requirement [2]. This study will emphasize and discuss HRM in the construction of a sustainable development project as the main factor for success of the construction project. In addition, it will also analyze the factors that influence HRM and discover the methods or ways to enhance and improve it.

\section{Human resource management in the construction of a sustainable development project}

Construction has been studied all over the world in terms of HRM in many countries such as in Europe, Australia and even Asia. A lot of journals, theses, case studies and books have been produced regarding human resource in the construction of a sustainable development project. The authors' analysis varies according to their experiences and research but all has been done for one main goal which is the impact of HRM in the construction of a sustainable development project. Previous research has been unable to really prove the effectiveness of HRM and techniques for improvement. HRM is defined as a field of organizational activity and professional practice which has a complex and unclear entity, variously interpreted by practitioners and researchers [1]. Slotte et al. [2] defined HRM as covering functions related primarily to training, career development, organizational development, and research development. In addition, human resource functions to foster learning capacity at all levels of the organization, promote learning culture into its overall business strategy and to enhance the organization's efforts to achieve high quality performance" [2]. $\mathrm{HRM}$ as an academic discipline includes the development of knowledge and expertise, and the enhancement of performance [3]. A forceful HRM system is also the most valuable asset of $21^{\text {st }}$ century construction companies, as an enterprise's productivity is closely correlated with its strategies [4]. With rapid changes in technology, workers' needs, current market, and competitive environment, planning for human resources has become an important and 
challenging task for development. Human resource planning involves plans for the future needs of employees, their required skills, acquisition of employees, and personnel development.

\subsection{Project success}

HRM has had its own consequences towards the success of a sustainable development project. The empirical study done by Pinto and Holt [5] indicated the positive impact of effective HRM by concluding that it was a factor for project success [6]. According to Pinto and Holt's studies, they have concluded that there were ten success factors for a project.

1. Project mission: initial clarity of objectives and general directions.

2. Project schedule: a detailed specification of the individual action steps required for project implementation.

3. Client consultation: communication and consultation; listening to all parties involved.

4. Technical tasks: availability of the required technology and expertise to accomplish the specific technical action steps.

5. Client acceptance: the act of "selling" the final projects to their ultimate intended users.

6. Monitoring and feedback: timely provision of comprehensive control information at each stage in the implementation process.

7. Communication: the provision of an appropriate network and necessary data to all key actors.

8. Trouble-shooting: ability to handle unexpected crises and deviations from plan.

9. Management support: willingness of top management to provide the necessary resources and authority/power for project success.

10. Personnel (recruitment, selection and training): recruitment, selection and training of the necessary personnel for the team.

Personnel was placed at number 10 in the success factor of a project. This means that people have less contribution to the success of a project which is very surprising. The authors of this journal tried to argue by doing another study adapted from Pinto and Holt [5], the Project Implementation Profile (PIP). By performing the PIP, it was realized that project success depends on the life cycle stage of a project which is the conceptual stage, planning stage, execution stage and completion stage.

\subsection{Policy and practice}

Within the typical HRM literature, there was a long tradition of research arguing that in order to make an optimal contribution to firm performance, HRM policies and practices should be integrated both with a firm strategy - so-called vertical strategic integration [7] - and with each other - so-called horizontal integration [8]. The orientation of the HRM function, its goals and aims, needs to be aligned 
with the strategy of the organization. If "managing by projects" was considered as the strategy of the project-oriented company [9], it would imply that the HRM policies, processes, and practices in the project-oriented company are in some way supportive of project-oriented working. It differs from traditional HRM processes and practices which are designed for the classically-managed organization. The emphasis is not on projects but instead on routine products and services. In addition, the job requirements are well defined and stable. There was a major difference between typical HRM and management based on a projectoriented company. HRM changes due to the people itself and the working environment. Management should apply their policy and strategy according to the needs of its employees. This is to ensure that they can respond positively and contribute to the company [10].

\subsection{Training}

There was an argument as to whether the level of skill among the labors contributed a significant effect toward project success or vice versa. Training and development was defined as a process of developing work-related knowledge and skills of employees for the purpose of improving the projects performance systematically [11]. Managers, executives, and supervisors influenced the transfer of knowledge and skills to their subordinates [12]. The training of extension personnel contributes directly to the development of human resources within extension organizations. Training has to start with the recognition of training needs through job analysis, performance assessment, and organizational analysis. Once the training needs have been identified, the next step is to organize training programs. Methods such as role-playing, simulation exercises, and case studies can be used in the training of human resources in the construction of a sustainable development project. One of the most important factors in implementing HRM in the construction industry is the need for effective training. Managers also need to develop ways to measure the performance of their workers. A system of performance measurement is needed in order to monitor improvements among construction teams inclusive of guiding managers to display quality indicators on the job site. This will create awareness and encourage the participants to achieve improvement [13]. In fact, it is accepted that construction firms face a lot of difficulties in the training and development of their labor and staff. There are two significant methods of training construction workers which are on-the-job and off-the-job training.

\subsection{Skilled and unskilled labor}

Tabassi and Bakar in Mashhad, Iran [14] stated that the lack of skilled workers in the construction of a sustainable development project contributed to the damage caused by earthquakes in Iran.

According to Tabassi and Bakar, there were 4 types of laborers in construction projects. The results shown vary in terms of percentage of different types of labor in construction projects. Skilled labor formed only $20 \%$ of Mashhad construction workforce. In contrast, $50 \%$ of the workforce were 


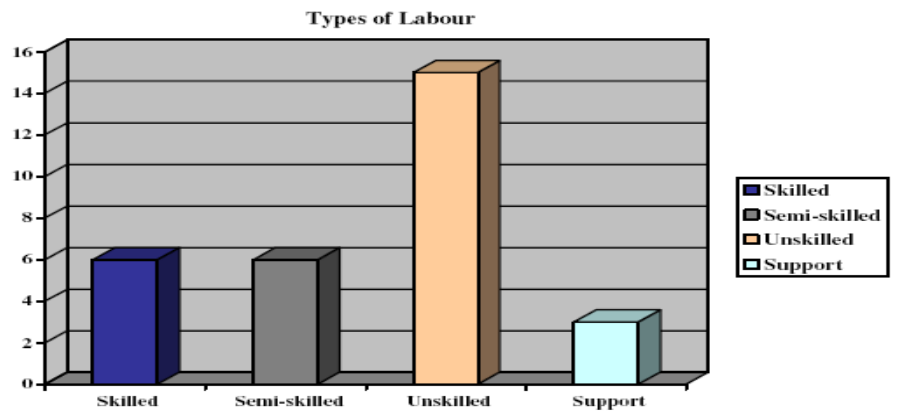

Figure 1: $\quad$ Types of labor in Iran [14].

unskilled and $20 \%$ were semi-skilled. This meant that most of the workers involved in the construction projects of Mashhad were unskilled. The research was then further continued by listing the reasons for the existence of more unskilled labor in construction projects.

Construction is the industry that use manpower in a large scale compared to other industries. Construction of a sustainable development project involves a variety of people starting from the clients, administrators, managers, designers, contractors, consultants, supervisors, foremen, skilled and unskilled laborers. These people all differ in terms of education, experience and views. Even though construction is viewed as an industry that uses the most of human resource due to its low technology and reliance on people, the attention given to its HRM issues is still inadequate and insufficient. According to the studies done on various construction projects all around the world, it shows that HRM issues and problems regarding the personnel and labor in construction greatly influenced the success and performance of a project. This project will analyze HRM in the construction of sustainable development projects, examining the strategic and operational aspects of managing people within the construction sector.

\section{Objective}

There are two objectives in this study. Firstly, to identify HRM as one of the key aspects in the success of constructing a sustainable development project. It also addresses a second objective in identifying the problems/issues of human resource in the construction of a sustainable development project and finds the methods to improve it.

\section{Methodology}

This research was carried out by literature review. It was then followed by data collection using questionnaires and interviews. The observation and monitoring on HRM approaches were conducted among contractors. The pilot survey was conducted to identify and ensure the effectiveness of the questionnaire survey. 
For the purpose of strengthening and further elaborating the survey, a case study was carried out on one of the construction sites located in Kuala Lumpur.

In the literature review, the research was focused on:

- The problems regarding HRM in the construction of a sustainable development project, and

- The methods used to improve HRM in the construction of a sustainable development project in the past.

The pilot survey or exploratory survey was a small scale methodological test intended to ensure that proposed methods and procedures would work in practice before being applied in a large and expensive investigation. The pilot survey was conducted among the students and staff of Universiti Teknologi PETRONAS and a contractor's company in Malaysia.

The aim of the data collection was to gather information regarding HRM and human resource itself in construction site. The data collection was conducted using qualitative research which is concerned with testing the theory presented in the objective. The data collections were undertaken in two ways:

\section{- Questionnaire}

This was the main alternative to gather information. People are more truthful while responding to questionnaires regarding controversial issues, in particular due to the fact that their responses are anonymous. The questionnaire survey was distributed to contractor companies all over Malaysia and it was conducted online. The author distributed the questionnaires to contractor companies all around Malaysia and received feedback from 25 companies altogether. The questionnaire consisted of three sections: General Information, Problems/Issues of HRM in the Construction of a Sustainable Development Project and Methods to Improve HRM in the Construction of a Sustainable Development Project. For this section, the respondents were asked about their background. The questions that had been asked were:

- Years of experience in construction projects;

- Number of projects they had been involved in;

- The importance of HRM in the construction of sustainable development projects;

- Case study/interview.

Case study/interview was a second alternative to gather information. The research was carried out by asking questions regarding HRM in the construction of sustainable development projects. This type of data collection has a distinct advantage of enabling the researcher to establish understanding with potential participants. The interview also allowed the researcher to clarify ambiguous answers and to seek clarification. The case study was carried out at the project site of the Home Ministry of Malaysia Complex in Kuala Lumpur. This project 
contains 1 block of administration building ( 7 storey) and 1 block of community building (3 storey) and is located on Lot 53782, Sri Hartamas, Kuala Lumpur. This project commenced on April 2009 and was scheduled for completion in December 2011. The client was the Home Ministry of Malaysia and the Project Director, Public Works Department assigned Asas Meranti - Tidalmarine JV (AMTMJV) as the main contractor for this project. Since the project is a "design and build" type, AMTMJV had assigned Mega Consult Sdn. Bhd and Dr. Nik \& Associates Sdn. Bhd as the civil and structural consultant and Conlay Construction Sdn. Bhd as the sub-contractor. The construction of the project had achieved $95 \%$ completion. The remaining works that needed to be done for completion before handover were the landscaping, road and clearance of site.

\section{Results and discussion}

\subsection{General information}

The years of experience of the contractors in the construction of sustainable development projects are reflected in the reliability and accuracy of the responses received. The authors had divided the respondents into two groups according to their experience - the group that had less than 5 years of experience and the group which had more than 5 years of experience in construction projects. The group which had less than 5 years of experience was $44 \%$ and could be considered as young contractors or young engineers while the other group which was $56 \%$ could be considered more senior in construction projects.

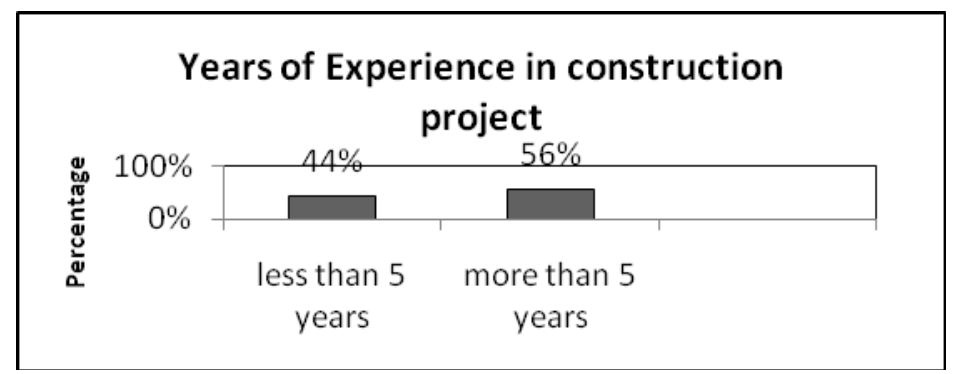

Figure 2: $\quad$ Years of experience in construction projects.

The number of projects that the contractors had been involved in can also be taken into consideration to add validity to the response. There was no contractor involved in only one project. The percentage for the contractors that had been involved in more than 5 projects was $20 \%$, the same percentage as the contractors involved in two projects. This can be considered as a good combination with regards to the questionnaire to see the difference in opinion between the contractors.

In the general information section, the authors had asked the respondents regarding the importance of HRM for the success of construction of the 


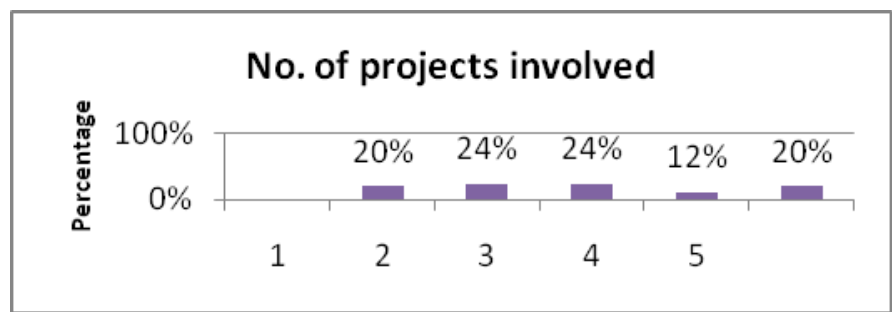

Figure 3: Number of projects involved in.

sustainable development project among them. All the respondents had given positive responses to this question; they had agreed that HRM was important for the success of construction of a sustainable development project.

\subsection{Problems of human resource management in the construction of a sustainable development project}

Most of the respondents agreed that project managers should play their role in implementing HRM to their subordinates. Insufficient duration of a project for the implementation of human resources got the lowest average index. The person who has the power to give orders at the construction site can execute the plan for HRM to engineers, consultants, supervisors, foremen and even laborers. Lack of communication ranks second; according to the survey. This problem was quite crucial in the construction project as, for example, if the communication between the staff and workers was not well implemented, the flow of information from the top management to the subordinates would not be achieved smoothly. The third ranking was insufficient teamwork in the construction of a sustainable

Table 1: Problems of human resource management in the construction of sustainable development projects.

\begin{tabular}{|r|r|c|}
\hline Rank & $\begin{array}{c}\text { Problems/issues } \\
\text { Project managers plays an important role }\end{array}$ & 4.68 \\
\hline 2 & $\begin{array}{c}\text { Lack of communication between personnel and } \\
\text { laborers }\end{array}$ & 4.64 \\
\hline 3 & Teamwork in the construction team is insufficient & 4.56 \\
\hline 4 & Lack of skilled laborers & 4.52 \\
\hline 5 & Training provided is not enough and inadequate & 4.32 \\
\hline 6 & No or lack of evaluation for the personnel and \\
laborers' performance & 3.20 \\
\hline 7 & $\begin{array}{r}\text { No or insufficient reward for personnel and } \\
\text { laborers with good performance }\end{array}$ & 2.92 \\
\hline 8 & $\begin{array}{c}\text { Duration of projects too short for HRM } \\
\text { implementation (1 year, 2 years, and so on) }\end{array}$ & \\
\hline
\end{tabular}


development project. The lack of teamwork can lead to disagreements between the personnel and, even worse, can affect the performance of a project. The respondents had ranked the problem of insufficient duration of project for HRM implementation as the lowest. This problem may be insignificant due to the mindset that HRM only can be executed over a long period of time instead of a short period of time.

\subsection{Methods to improve human resource management in the construction of a sustainable development project}

Many respondents agreed that frequent communication between personnel and laborers would improve HRM, thus improving the performance of project. With good communication among the managers, engineers, consultants, contractors, supervisors, foremen and laborers, any arising matter regarding progress and problems at the construction site can be handled effectively and systematically. The second rank was appointing an experienced or well-trained project manager. By doing this, the particular project manager can organize and handle his/her construction team more effectively. Assigning skilled workers was also considered important in projects. The works on-site would definitely progress better if a lot of skilled workers were being assigned. This will certainly improve the overall performance of projects. As for the lowest rank; reward to personnel and laborer with good performance seems to be less effective to the people involved in the construction of a sustainable development project.

Table 2: $\quad$ Methods to improve human resource management.

\begin{tabular}{|c|c|c|}
\hline Rank & Methods & Average Index \\
\hline 1 & $\begin{array}{l}\text { Ensure frequent communication between } \\
\text { personnel and laborers }\end{array}$ & 4.64 \\
\hline 2 & $\begin{array}{l}\text { Appoint experienced or well trained project } \\
\text { managers to handle project }\end{array}$ & 4.56 \\
\hline 3 & Assign more skilled workers in project & 4.48 \\
\hline 4 & $\begin{array}{l}\text { Ensure participation and team belonging is } \\
\text { developed in the construction team }\end{array}$ & 4.48 \\
\hline 5 & $\begin{array}{l}\text { Evaluation of personnel and workers conducted } \\
\text { regularly }\end{array}$ & 4.16 \\
\hline 6 & Provide sufficient and effective training & 3.52 \\
\hline 7 & $\begin{array}{l}\text { Start the team building even before the project } \\
\text { starts (during conceptual stage) }\end{array}$ & 2.72 \\
\hline 8 & $\begin{array}{l}\text { Provide reward for personnel and laborers with } \\
\text { good performance }\end{array}$ & 2.04 \\
\hline
\end{tabular}




\subsection{Case study}

The Project Manager for this project, Mr. Abang Abdul Halil Abang Naili, was the main contractor said that HRM should be more focused on communication and the spirit of teamwork in the construction team. The key to success in the construction of a sustainable development project was teamwork, with an in-built mechanism for communication from everyone in the construction site. The channel of communication should flow freely from top to bottom and also from the bottom to the top. This will strengthen the teamwork in the construction team and hence increase the performance of that particular project. As for the subcontractors, their view towards HRM was more towards the laborers and supervisors on-site. According to Mr. Wan Mohd Nazim Wan Muhammad, one of the sub-contractor in this project, the problem at the construction project was to get the skilled workers, particularly in specialized fields, such as the post tensioning work. By assigning more skilled workers, the project's performance and workflow will undoubtedly increase by a large margin. They had a case on this site where progress had been delayed due to a problem regarding the post tensioning work. The slab concreting process had been put on hold for about 2-3 weeks because of this problem. The reason for the delay was due to the slow installation of the post tensioning work that had been caused by a lack of skilled workers for the respective task. The problem had been solved by bringing in the skilled workers and the progress for the project had increased significantly.

Table 3 shows that the progress of the site was very slow from February 2010 to March 2010 but had increased significantly from March 2010 to April 2010. According to Mr. Nazim, this was the time when the skilled workers for the post tensioning work had been brought in. He also added that starting on April 2010 and the remaining months the site had been able to cast four slabs in a month.

Table 3: $\quad$ Project's progress for three consecutive months.

\begin{tabular}{|c|c|c|c|c|}
\hline & $\begin{array}{c}\text { Scheduled } \\
\text { Progress }\end{array}$ & $\begin{array}{c}\text { On-site } \\
\text { Progress }\end{array}$ & $\begin{array}{c}\text { Fast }(+) / \\
\text { Late }(-)\end{array}$ & $\begin{array}{c}\text { Number of days Fast } \\
(+) / \text { Late }(-)\end{array}$ \\
\hline Feb. 2010 & $60 \%$ & $57 \%$ & $-3 \%$ & -30 days \\
\hline Mar. 2010 & $65 \%$ & $61 \%$ & $-4 \%$ & -40 days \\
\hline April 2010 & $70 \%$ & $69 \%$ & $-1 \%$ & -10 days \\
\hline
\end{tabular}

\section{Conclusion and recommendation}

Based on the research done, it can be concluded that HRM in the construction of a sustainable development project needs to be further improved from time to time for its effectiveness. From the survey and the case study, the authors believe that the contractors in Malaysia had an awareness of HRM in the construction of a sustainable development project. However, improvements in many aspects need to be considered in order to ensure the effectiveness of HRM. The first objective of this study which was to determine HRM as one of the key aspects for the success of construction of a sustainable development project had 
been achieved. All the respondents in the survey and the case study had agreed that HRM was important for the success of construction of a sustainable development project. The second objective; to identify the problems/issues of human resources in the construction of a sustainable development project had also been achieved. The respondents had given their various opinions and views towards the subject matter. Even though the responses given varied from one person to another, the authors believed that the feedback obtained was reliable and accurate considering the fact that the respondents were from the contractor's company. The authors suggest that, for further research, the survey needs to be carried out in a larger scope. Instead of involvement only from contractors' opinions, the authors believe that, by involving other parties inclusive of the consultants, suppliers and even the clients in the survey, the results will be much more reliable, adequate and applicable towards the construction of a sustainable development project in Malaysia. The authors also suggest that the methods to improve HRM that have been discussed in the survey can be put into practice by the contractors' companies. As the feedback of the survey came from the contractors themselves, the authors strongly believe that the methods were effective to improve HRM in the construction of a sustainable development project for the betterment of not just the contractors but also for consultants, clients and even the country.

\section{References}

[1] Sharon M, Philip W, Brenda S, David S, Chris R, Francine W. Developing " "new commons" between HRD research and practice. Case studies of UK universities. J Eur Indust Training 2007; 31(1): 4-18.

[2] Slotte V, Tynjala P, Hytonen T. How do HRD practitioners describe learning at work? Human Resour Dev Int 2004; 7(4): 541-4.

[3] Garavan TN, Morley MJ. Re-dimensionalising boundaries in the theory and practice of Human Resource Development. Learn Intellect Capital 2006; 3(1): 3-13.

[4] Liang-Hsuan C, Shu-Yi L, Tzai-Zang L. Using an HRM pattern approach to examine the productivity of manufacturing firms - an empirical study. Int J Manpower 2003; 24(3): 299-318.

[5] Pinto JK, Holt GD. (1988). Variations in critical success factors over the stages in the project life cycle. Journal of Management 14(1), 5-18.

[6] Belout, A., Gauvreau, C. (2004). Factors influencing project success: the impact of human resource management. Int $J$ of Project Management 22 (1), 1-11.

[7] Lengnick-Hall CA, Lengnick-Hall ML. Strategic human resources management: a review of the literature and a proposed typology. Acad Manage Rev 1998; 13(3):454-70.

[8] Wright PW, Boswell WR. Desegregating HRM: a review and synthesis of micro and macro human resource management research. J Manage 2002; 28(3): 247-76.

[9] Gareis R, editor. Management by projects. Vienna: Manz; 1990. 
[10] Keegan AE, Turner JR. Managing human resources in the project based organization. In: Turner JR, editor. People in project management. Aldershot: Gower; 2003. p. 1-12.

[11] Wright P, McMahan G. Theoretical perspectives for strategic human resource management. J Manage 1992; 18(2): 295-320.

[12] Jong Jan A de, Leenders Frieda J, Thijssen Jo GL. HRD tasks of first-level managers. $J$ Workplace Learning 1999; 11(5): 176-83.

[13] Nesan LJ, Holt GD. Empowerment in construction: the way forward for performance improvement. England: Baldock, Hertfordshire, Research Studies Ltd; 1999.

[14] Tabassi, AA, Abu Bakar AH, (2008). Training, motivation and performance: the case of human resource management in construction projects in Mashdad, Iran, Int J of Project Management 27 (2009) 471-480: 3-8 